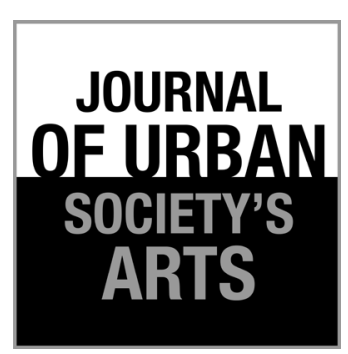

Volume 6 Nomor 2,

Oktober 2019: 81-86

\title{
Revisionist Architecture
}

\author{
Karim Raef Fouad Gorgi
}

Department of Architecture, Faculty of Fine Arts, Alexandria University, Egypt

E-mail: karimgorgi@hotmail.com

\begin{abstract}
ABSTRAK
Arsitektur Revisionis. Artikel ini memperkenalkan rekonsiliasi serta analisis kesenjangan antara estetika kontemporer dan klasik dalam arsitektur. Analisis tersebut menguraikan segmentasi sebagai salah satu standar pada daya tarik estetika, yang disimpulkan dengan mengusulkan suatu rekonsiliasi dengan cara mengintegrasikan seni modern dan kontemporer ke dalam arsitektur saat ini. Rekonsiliasi ini tidak hanya berfungsi sebagai pandangan artistik pada arsitektur, tetapi juga meningkatkan kesadaran akan subjektivitas keindahan dalam arsitektur. Kesimpulan dari artikel ini adalah bahwa ilustrasi yang disorot menunjukkan hasil yang indah dengan menggunakan metode integrasi yang diusulkan ini.
\end{abstract}

Kata kunci: gaya ekspresionis; terpaku pada interior; arsitektur estetika

\begin{abstract}
This paper introduces the reconciliation as well as an analysis of the divide between contemporary and classical aesthetics in architecture. The analysis outlines the segmentation as one of the standards rather than of aesthetic appeal, concluding with a proposal for the reconciliation by means of integrating modern and contemporary art into today's architecture. This reconciliation would not only serve as an artistic take on architecture but also raise awareness of the subjectivity of beauty in architecture. In the conclusion of this paper, there are highlighted illustrations demonstrating the picturesque outcome of using this proposed method of integration.
\end{abstract}

Keywords: expressionist style; fixated on the interior; aesthetics architecture

\section{Introduction}

It is argued that the most conspicuous shift in the general history of architecture takes place between the neoclassical revivalist era, and the modern and postmodern age. Contemporary architecture has taken design through a whole new set of aesthetic form. From a certain viewpoint, one could dare say the entire aesthetic function of structures had changed drastically. For in designing a building, the contemporary artistic doctrine views the structure in question as its own work of art, like the architect's canvas or sculpture, whereas classical design treats the structure as a medium with which art is displayed. For the purpose of this paper, limiting the exceptionally broad term of "Classical", when referencing art and architecture, to its most layman allusion, which defines the term as any aesthetic before the twentieth century Is imperative to avoid the submergence into technicality. Similar use may be applied to the words "contemporary" and "modern" as well. Present-day eccentric architects often design with an eager use of freeform, such was the fundamental ideology of both the Deconstructivist and expressionist movements. Whether curvilinear or rectilinear design, the architect's focus prioritized two things above all else, the flow and form of the exterior appearance, as well as function and practicality of the interior plan. Whereas Architects of the past focused more on the framework which would present the adornment and artwork. In any palace, castle or church one would see how the architect framed each column, arch, cornice, pilaster, alcove, and even the plinth as mediums available for adornment; and thus, they were gilded, sculpted, and adorned in more ways than these pages would permit description. Even the ceilings, 
whether they would be vaulted into a ribbed web or frame dozens of frescoes and paintings with gilded courses. All of this resulted in an architecture so rich in style and elements. A simple proof would be the wide arrays of glossaries and the overall extensive terminology revolving around architecture.

It was Lewis (2009), in his column " $A$ Perfect Recipe For Boring Buildings", who highlighted the maxim that said, "Put three architects in a room, and you'll get five opinions." This Maxim, as humorous as it sounds, puts forth an argument into light which the notorious philosopher Kant (1970) took liberty to express its nature; the nature of aesthetics. In his book, Critique of Judgement, he explains, "In all judgements by which we describe anything as beautiful, we allow no one to be of another opinion." Kant argues not only beauty's subjectivity but also its perception as he explained it to be rooted in sensory, emotional, and intellectual aspects, which are not objective features. He goes further with his argument, demonstrating the absurdity of entitled opinion regarding beauty, with a simple anecdote, "...When he puts a thing on a pedestal and calls it beautiful, he demands the same delight from others. He judges not merely for himself, but for all men, and then speaks of beauty as if it were the property of things." Now, in the case of architecture, the established problem would be the extreme difference in aesthetics between the two ideals. This forced architects from all over the world to pick a personal preference and embark on a determined mission of imposing their standards and values upon whomsoever is willing to give an ear. Thus, a division in theory and principle would be created amongst architects, which poses a potential catastrophe when such a divide encourages professors and teachers to grow intolerant of the variant cases of theories opposing their own, and even going as far as stating an aesthetic theme as merely "wrong", spreading this intolerant nature in a way that twists the arms of art and all its foundations.

\section{The Proposed Approach}

As mentioned earlier, the entire philosophy of aesthetics between classical and modern architecture seemed to split the rising, ambitious architects into two groups: The forward-thinking modernists, and the art and culture-hungry classicists. Integrating contemporary art into the modern (and postmodern) architecture would satisfy the classical means of framing the structure into a gallery of art whilst maintaining the eccentric forms and ideals of the modernists. Though the nature of contemporary art remains under heavy controversy due to its constant evolution and challenges, its aesthetic qualities of colour and form are almost universally recognized. Most notably the art which deals with abstraction- In a way, the people who are more inclined to prefer classical architecture would consider this proposal as a sort of "Revisionist Approach" as they might consider the absence of artistry in architectural adornment as merely a product of ignorance or forgetfulness. Although, this may seem to contrast the societal criticisms validly presented forth by Loos (1998) in his essays concerning adornment known as "Ornament and Crime", it actually repairs the problem by liberating both the architecture and the adorning art, yet still have them work together to produce the final product. The artists and sculptors would become free to paint and sculpt whatever they pleased, whereas the architect would frame and plan the building to be practical and aesthetically consistent. Loos's critique of having the architect dictate the artists is thus answered as they both become partners rather than being positioned in a hierarchy. Contrary to his other claims however, art and adornment would be revered rather than oppressed, as the debt of having an aesthetically sustainable building includes the increase of expression in as many forms of art as possible.

\section{The Case For Contemporary Architecture}

Before rushing to the conclusion, proving the cases of the two rivals in order to find and form a foundation for the proposed reconciliation is paramount. The modernist critique of the classical style was quite expansive and elaborate. Modernist architects wished to thrive where each individual architect would come up with his own style of architecture and ultimately creating a vast array 
of possibilities for design. One thing they noted in classical architecture was its repetitiveness per era. Once viewed objectively in retrospect, the repetitive nature of any period known for its specific architecture could be seen without difficulty. It takes a vigorously trained eye to tell the difference between the facades of the Gothic Amiens Cathedral and the similarly Gothic Notre Dame de Paris. Modernist architects, one could easily assume, felt the confinement in the architecture of the time. Whether it be Gothic, Romanesque, Italian Renaissance, or even as late as the Victorian Queen Anne Style or the Second Empire style, the architecture was, more or less, dictated by the era and not the architect. This, as history is witness, did not sit well with these modern-day architects. The reason was not that they found classical architecture to be aesthetically inferior -they often revere it in fact- but rather because they long to discover the potential designs outside the confinement of society and inside the ample possibilities of their imagination. Especially at a time when the culture of art is heading in the same direction with movements such as surrealism, cubism, and abstract expressionism. The general ideal of art simply transferred into the hypnotic venue of the mind from the traditional concrete reality; and this, frankly, flattered the artists.

Another sound critique of classical architecture focused on its insistence of static solids in terms of the main structure. With the new structure systems available at architectural disposal, thanks to the brilliant and progressive work of Civil Engineers and computer programs analyzing the efforts of each column, modern day architects found themselves free from the restrictions past architects had to face. Now architects can design buildings that would reach as far as the clouds or spans that would hover over an entire street, or even curved surfaces that would make the structure seem to be under some kind of spell standing the way it does. And with such freedom, architecture grew more dynamic, it was no longer bound by the rectilinear small spaces to keep the structures stable. Thus, this dynamic element grew rather elaborate and even flamboyant with the rise of Postmodern architecture, especially deconstructivism, and resulted in the renowned, acclaimed works of architects such as Zaha Hadid and Frank Gehry, which gave off the impression of surrealism. There were also pattern-based designs, which humans are inherently attracted to in Parametric architecture as well as various cases of Art Deco. But then again, contemporary architecture could not be tamed, when complicated forms and complex arrangement abounds, simplicity and practicality abound as well, especially since simplicity in architecture often gives a sense of comfort. Contemporary architecture took many forms thence, with Organic architecture, Brutalist architecture, Art Deco, International Style, Minimalist architecture, and much more; each with its own set of characteristics and philosophy.

\section{The Case For Classical Architecture}

A reiteration is due, just in case some confusion should surface, when "Classical architecture" is references, it would be an allusion to the various styles of architecture starting from the Greek (and maybe Ancient Egyptian) all the way till the end of Beaux Arts and Eclectic architecture (which includes the slightly modern style of Art Nouveau). While most, if not all, modernist architects admire Classical architecture, conservative, nostalgic architects on the other hand have grown bitter and denounce Modern architecture quite heavily (Yet they do not deny its overall aesthetic quality). The main critique traditional architects have of Modern architecture is its copious cases of monotony and boring simplicity. Emphasized in the International style, Minimal architecture and Brutalist architecture; there had been a noticeable abandonment of ornamentation, form, and worst of all, the classical orders. The dispute then became one of standards rather than of aesthetic outcome. The lack of complex design rid the Modern buildings of any architectural reverence. Thus, conservative architects view the much-admired skyscrapers that soar high up to the clouds as feats of engineering and not feats of architecture. Not only so, but what vexes these romantics even more is the evident change in philosophy as compared to the classical style, for, in the past, spires and bell towers where 
what scraped the sky and not the corporal buildings of this age. All this displayed a sort of dystopian narrative as the switch from spires, that pointed to a God in humility and praise, to corporate towers highlighted the philosophy of modern man: $\mathrm{He}$ became his own God. Classical architecture is held to a higher standard in terms of "awe factor" where a simple visitor not only would admire the various ornaments and paintings -maybe even mosaics- but also the presence of a rich history backed with all kinds of cultural significance. One would not enter the Sistine Chapel, for instance, without thinking about Michelangelo, Botticelli, various Popes, the early Christians, as well as theology. One would not enter St. Mark's Basilica without thinking about the Byzantine Empire, the horses of St. Mark, the Tetrarchs, various Byzantine emperors, as well as the Doge and his palace. Every Classical building tells a thousand stories, this highlights and glorifies human history. Not only so, but the eyes would also have a thousand things to look at, if the mind finds learning history a tedious task, since Architect, Painter and Sculptor worked in harmony to develop one beautiful structure. This turned out rather rare as time passed by when the economies grew more fragile and the people, especially civilians, sought to build but under a budget. This became evident during the age of Enlightenment, after the baroque period, and especially during the Victorian era. Budget, however, did not stop the architects from dreaming nor the harmony from its symphony, as styles like the Queen Anne style and its continued revival, Jacobethan style, Richardsonian Romanesque, Second Empire architecture, and Italianate did not forsake sculpting but rather tamed it in a rather nonostentatious manner. Sculpting, then, took a more architectural role by decorating corbels, keystones, column capitals, cornices, finials, pediments, balustrades, as well as many other elements that were crucial for an overall decent aesthetic quality (maybe even an occasional statue like the statue of Jesus in the John Hopkins Hospital). Such was the case with residential buildings, the era, however, also included many structures, secular and religious, that had a relatively large budget and thus came the revivals of the extravagant Gothic architecture and the Renaissance architecture. Classical Architecture, shortly after, reached an alltime high with movements such as the Beaux Arts and Eclecticism as the philosophy of architectural aesthetics opened its arms and accepted all forms of art and architecture into one work at a time.

\section{The Reconciliation And Integration}

This divide in aesthetic belief has become more prominent over the years as more students study Architecture History and formulate their own preference. And if this divide keeps growing, there will be a constant halt in the evolution of architecture since the dispute relies heavily on the first principles of design and the philosophy of beauty.

Thus, what the architectural world is in dire need of, is a reconciliation, not of classical and modern architectural elements, but of classical and modern standards. Meyer Schapiro, a Lithuanianborn American art historian, considered the constant change in the art world in his essay "Nature of Abstract Art". He considered two scenarios with which art movements arise, Exhaustion and Reaction or otherwise known as the "Grandfather Principle" (which he was not very fond of), and the historical and culture-based reaction. The Grandfather Principle frames art movements into cycles of the exhaustion of one and the reaction against it, creating another style. This view, Meyer Schapiro found too mechanical and negligent of "sources of energy and the condition of the field", which means, it does not put into consideration the certain effects society and history had on art. Thus, unless the older art styles be found inadequate and exhausted, newer art styles and movement are more inclined to be based on the development of culture and civilization, especially with the exponential rise of globalization. After all, such was the case with Modern architecture as its relation to the industrial revolution was closely correlated. In this case, both axioms apply, for conservative architects do, indeed, believe that Modern architecture is inadequate; in fact, that's their main concern. On the other hand, society's evolution has reached an era of inclusion, whether in art or in politics, people have generally grown more open and accepting to new ideas. 
That said, there are two schemes, as far as thought can go, that can dissolve the highlighted dispute into a reconciliation. The first that may generally come to mind is a sort of neo-eclectic architecture, where Modern architecture would treat classical architecture in the same manner Renaissance architecture treated Greek and Roman architecture, applying the new ideas and styles yet maintaining the same principle elements like the pediment, column orders, and symmetry. In the case of a neoeclectic style, one would see deconstructed classical buildings or high-rising classical towers like the Woolworth building, or highlighted contrast like I. M. Pei's Louvre Pyramid and the Bundeswehr Military History Museum in Germany. The second scheme is the main proposal of this paper: the integration of contemporary art into architecture. The first question which may arise is: Where would this apply? To answer this bluntly, dominantly, existing capitalism has enabled individuals, in the case of microeconomics, to earn net-worth without any limits and consequently budgets have grown proportionally to produce extravagance. Whether palace-like villas, museums or universities, flamboyant taste abounds. Vitruvius, the Roman author of "The Ten Books On Architecture" had said, "Architecture is a science arising out of many other sciences, and adorned with much and varied learning; by the help of which a judgment is formed of those works which are the result of other arts."

As Architecture is widely considered an art major, it is imperative to treat it as such and integrate it, as with conventional art, with the rest of the art world. Thus, as conclusion bids, one must learn where has the art world been in the

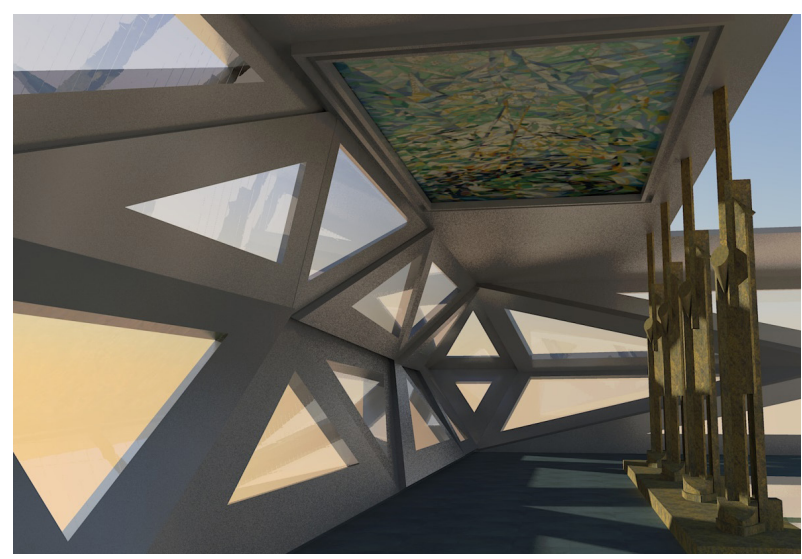

Figure 1. Fixated on an interior design. recent years. The dominating movements of art in these modern times are mostly what is considered "Abstraction" where one deals with more than the material imitations of nature but rather the deep expressions of perspective, whether it be Abstract expressionism, Cubism, De Stijl, Vorticism, Rayonism, Suprematism or Futurism (Even on the occasions they overlap). Though, the integration may work with any form of contemporary art such as Color Field, Digital art, or even Hyper Realism.

To further the cause, I shall resort to figures 1 and 2 in order to elaborate more efficiently. In these two illustrations, which I made using a computer aid design programs, I will explain methods with which contemporary art may be applied to architecture.

The main inspiration for figure 1 was The Hall of Mirrors of the palace of Versailles. The method of showcasing art is similar yet strangely contrasted in appearance, for instead of frescoes on the ceiling framed with gilded foliage and supported by golden Corinthian - or composite - columns all of which pertain to the Louis XIV style, we have a futurist painting frescoed on the ceiling, framed by a false-ceiling, and supported by what seem to be Cubist sculptures all of which are subject to the building's Deconstructivist form. Here, I focused on a generally Cubist theme, bearing in mind what the beholder would see. At first glance, one would regard the general aesthetic in all its geometric glory, considering the form of the structure first, which serves not only as an aid to the general aesthetic but also its own art work, it does not need the rest of the art pieces to have its appealing effect. Second, the eye would wonder to the fresco on the ceiling

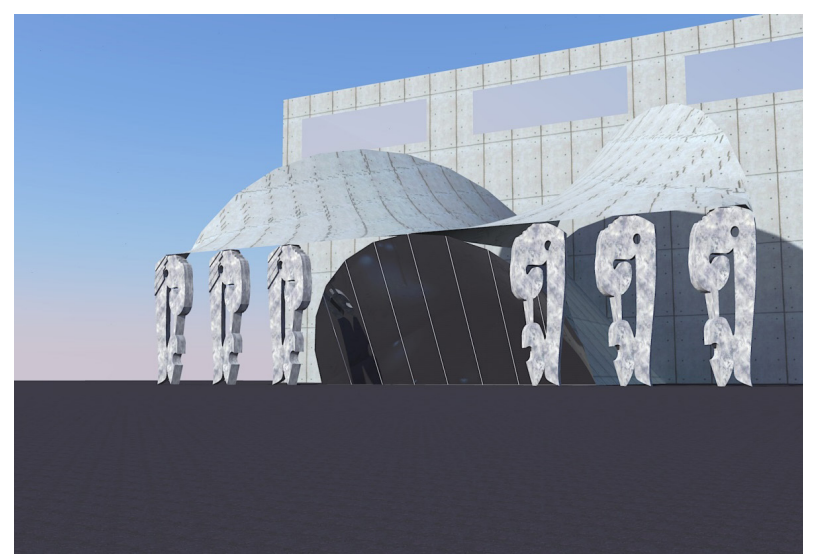

Figure 2. Expressionist architectural style. 
which is actually a painting made by the brilliant Joseph Stella called "Spring"; and though he is a futurist, this painting in particular is analyzed by Irving Lavin from a Cubist perspective; one may even go as far as saying Cubisme Analytique, due to its uniform and earth-bound color pallet (Lavin, 1961). The painting invites the onlooker, as the analysis goes, to look at a scene or landscape in springtime through a myriad of eyes, or as though looking through a shattered glass. As for the Cubist columns, which are my poor attempts of a sculpture - or a digital replica - inspired by a Jacque Lipchitz sculpture simply known as "Sculpture 1915-16" since the artist didn't officially name it. It is said that he described works like this as "Abstract architectural sculptures". The most prominent analysis of the sculpture is its portrayal of a man seated on a table. The sculpture is currently in the collection of the Tate gallery.

With all this in mind, it is understandable to think that the visitor will take his time to marvel at all the art before him and maybe even get lost in its abstraction. It was Kandinsky (1977) that said, "lend your ears to music, open your eyes to painting, and ... stop thinking! Just ask yourself whether the work has enabled you to "walk about" into a hitherto unknown world. If the answer is yes, what more do you want?"

The theme in figure 2 took a different route, as I tried to focus and sync the Expressionist architectural style with the Abstract Expressionist sculpture, which happens to be inspired by an Isamu Noguchi sculpture known as "My Pacific", used as a column order. Thus, we have two elements to which the observer may admire instead of one and this considerably increases the aesthetic quality.

\section{Conclusion}

I reach my conclusion in proclaiming that with the unity of painter, sculptor and architect, the potential for creativity becomes unparalleled, as one may once again use paintings for a surreal appeal and not be limited by the three - or five main column orders, but rather a million orders as far as sculpting can go. Even the Romans and Greeks occasionally grew tired of the conventional column orders and used the Caryatid and Atlas as columns - or architectural supports -, but this time, in this case, limit is no longer a problem.

The idea of this paper is posed as a mere fundamental principle on which possibilities of design as well as the potential of creativity, then, become endless and move along the rest of the art world in a more symphonic harmony. A synchronization of contemporary form and adornment.

\section{References}

Kandinsky, W. (1977). Concerning The Spiritual In Art. New York: Dover Publications Inc.

Kant, I. (1970). Critique of Judgment. New York: FREE Press.

Lavin, I. (1961). Abstraction in Modern Painting: A Comparison. The Metropolitan Museum of Art Bulletin, 19(6), 166-171.

Lewis, R. K. (2009). A Perfect Recipe for Boring Buildings. Accessed: 2nd February 2019. https://www.washingtonpost.com/ wp-dyn/content/article/2009/05/15/ AR2009051501480.html

Loos, A. (1998). Ornament and Crime: Selected Essays. Riverside: Ariadne Press. 